\title{
Major oncological surgery reduces muscular function in patients with or without nutritional risk
}

\section{Cirurgia oncológica de grande porte reduz a função muscular de pacientes com e sem risco nutricional}

Jessika Cadavid Sierra ${ }^{1}$ (iD; Diana Borges Dock-Nascimento ${ }^{2}$; Thayse Emanuelli Godoy Behne ${ }^{1}$; Mariana Borges Silva Thé 4 ; Hadassa Hillary Novaes Pereira Rodrigues²; Francilene Oliveira Andreo'; Maristela luft Palauro; José Eduardo de-Aguilar-Nascimento, TCBC-MT1,4

\section{A B S T R A C T}

\begin{abstract}
Objectives: to investigate the impact of oncological surgical procedures on the muscle function of patients with and without nutritional risk. Methods: cross-sectional study conducted with cancer patients undergoing major operations between July 2018 to March 2019 in Cuiabá, Mato Grosso, Brazil. Patients were assessed preoperatively for the nutritional risk by the Nutricional Risk Screening-2002, and handgrip strength (FPP) was assessed both on the pre- and 2nd and 5th postoperative days (PO). Results: 92 patients were evaluated, of whom $55.4 \%$ were men and $44.6 \%$ women, with a mean age (SD) of 64 (10.81) for patients at risk and 51 (12.99) for patients without nutritional risk. The preoperative nutritional risk evaluation indicated that $34.8 \%$ of the patients had no risk and $65.2 \%$ had a nutritional risk. The FPP was lower $(p=0.008)$ in the group with nutritional risk in the preoperative period. In both groups, there was a significant drop in FPP on the 2nd PO day. The preoperative FPP compared with the 2nd PO FPP was more pronounced in patients without nutritional risk $(p=0.039)$. Patients with nutritional risk had a longer hospital stay $(p=0.049)$. Conclusion: surgical trauma causes loss of muscle function in the early PO. Patients without nutritional risk have a more significant decrease in muscle strength after surgical oncological procedures than those with nutritional risk. These results may infer the need to implement pre-habilitation in all patients who will undergo major oncological procedures.
\end{abstract}

Keywords: Surgical Procedures, Operative. Neoplasms. Muscle strength Nutritional status. Length of Stay.

\section{INTRODUCTION}

C ancer is a disease that compromises the nutritional status, leading to morphological, functional, and metabolic changes. The surgical treatment is common when it comes to cancer therapy. Nutritional status before surgery and how it is affected by the surgical trauma are determinant factors regarding postoperative loss of muscle mass and functional capacity'. Various authors have shown that malnutrition is highly prevalent among surgical patients, with a prevalence rate of 35 to $60 \%{ }^{2}$, and it is often frequent in cancer patients at the moment of diagnosis ${ }^{3}$. Worsening of nutritional status directly impacts skeletal muscle fiber, leading to progressive loss of muscle mass and strength, and consequently, muscle function loss, known as sarcopenia ${ }^{4}$.

Functional capacity loss negatively impacts patients' daily routine activities, quality of life, early postoperative mobilization, and ultimately increases the risk of postoperative complications ${ }^{5-6}$. Protocols like ACERTO (Aceleração da Recuperação Total PósOperatória), and ERAS (Enhanced Recovery After Surgery) focus on the importance of prehabilitation, which is a combination of both physical exercises and adequate nutritional management, reducing postoperative complications, hospital stay and overall

1 - Universidade Federal de Mato Grosso, Programa de Pós-Graduação em Ciências da Saúde, Faculdade de Ciências Médicas - Cuiabá - MT - Brasil 2 - Universidade Federal de Mato Grosso, Faculdade de Nutrição - Cuiabá - MT - Brasil 3 - Centro Universitário UNIVAG, Faculdade de Nutrição Várzea Grande - MT - Brasil 4 - Centro Universitário UNIVAG, Diretoria curso de Medicina - Várzea Grande - MT - Brasil 
mortality $^{7-11}$.

In the last few years, much attention has been given to nutritional risk, which often precedes malnutrition. Patients at nutritional risk are more likely to have postoperative complications and longer hospital stay $^{12,13}$. Thus, early identification of both nutritional risk and muscle function loss helps reduce postoperative complications and hospital costs ${ }^{14-16}$. However, such information can be misleading, impacting the attention given to those patients without nutritional risk. However, all patients undergoing major operations suffer from surgical aggression. Thus, we hypothesize that the surgical procedure impacts the muscle function of all oncologic patients, regardless of their nutritional risk. No previous studies, that we are aware of, have compared the evolution of muscle function after major procedures among oncologic patients with and without a nutritional risk. However, one study has shown that patients identified with no nutritional risk are more likely to have postoperative complications if sarcopenic in the preoperative period ${ }^{17}$. Thus, we aimed to assess whether or not surgical procedures affect postoperative muscle function of both cancer patients with and without nutritional risk

\section{METHODS}

This is a prospective study conducted between July 2018 and March 2019. Oncologic patients from the Brazilian Unified Health System (known as SUS) admitted to two hospitals in Cuiabá, Mato Grosso - Brazil (Santa Casa da Misericórdia and Hospital do Cancer) for major operations were included. The study was approved by the Universidade Federal de Mato Grosso ethics committee (number 2.666.168), in accordance with the resolutions 466/12 and 196/16 of the National Health Council. All subjects were informed and signed the Informed Consent Form (ICF). Major operation was defined as with that with a duration longer than 2 hours and classified level II by the SUS ${ }^{18}$. Data collection was carried out within the first 48 hours after hospital admission, as well as on the second and fifth postoperative days. All data were collected by the main researcher and by graduation and post-graduation nutrition students, Universidade Federal do Mato Grosso. Both the researcher and the students were previously trained for the data collection.

Exclusion criteria were surgical duration $<120 \mathrm{~min}$, and death before the $5^{\text {th }}$ postoperative day. Patients that, for any reason, were unable to perform the handgrip strength test on the second or $5^{\text {th }}$ postoperative day were also excluded.

\section{Nutritional risk}

Preoperative NRS-2002 score (Nutritional Risk Screening-2002) was used to classify patients as follows: no nutritional risk (NRS $<3$ ) or at nutritional risk (NRS $\geq$ $3)^{19}$.

\section{Muscle functionality}

The main measured outcome was handgrip strength (HGS), which was assessed in three moments: preoperatively (HGS-PRE), on the second postoperative day (HGS-POD2), and on the fifth postoperative day (HGSPOD5). A hydraulic dynamometer (Saehan Corporation, Masan, Korea $\left.{ }^{\circledR}\right)$ was used. Patients were seated, with elbows $90^{\circ}$ flexed, making three maximum contractions with a pause of 1 minute between measures, as standardized by the American Society of Hand Therapists $-\mathrm{ASHT}^{20}$. The mean of the three dominant hand measures was used.

Data included sex, age, weight, usual weight, preoperative non-intentional weight loss, type of surgery, surgical length, ASA (American Society of Anesthesiologists) score, duration of postoperative fasting, and length of hospital stay. Data were collected directly with the patient or with a family member (after the ICF was signed) or extracted from the medical records.

\section{Statistical analysis}

The repeated-measures ANOVA was used to compare the results of the HGS, at the three perioperative moments, of the two groups of patients previously classified as with or without nutritional risk. Student's t-test was also used to compare the other variables between the two groups. The results are presented as mean and standard deviation (SD). A $p<0.05$ was considered to be statistically significant. All statistical analysis were 
performed using SPSS version 22.0 (Statistical Package for the Social Sciences).

\section{RESULTS}

One hundred eighty-seven patients were considered eligible for the study. However, 95 were excluded regarding the exclusion criteria. The study flowchart is presented in figure 1.

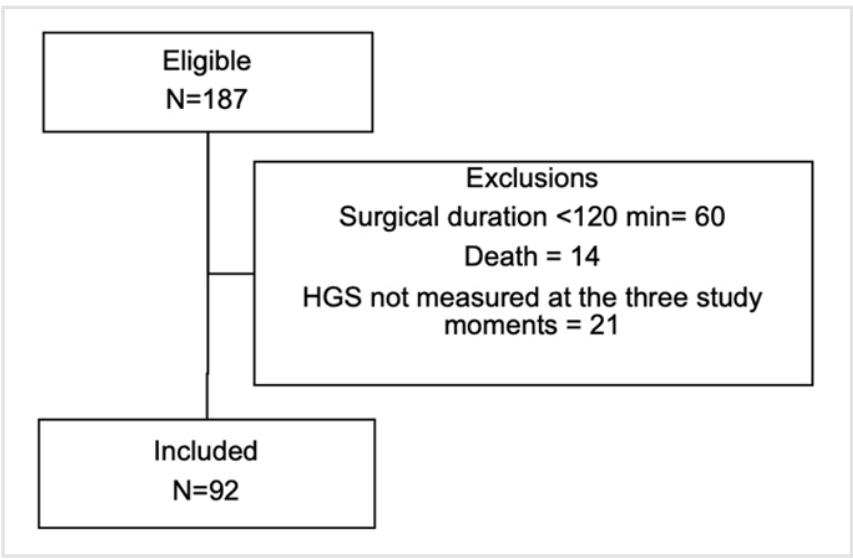

Figure 1. Study flowchart.

Preoperatively, more than half of the patients $(65.2 \%, n=60)$ were classified as presenting a nutritional risk, according to NRS-2002, while $1 / 3$ did not have nutritional risk (34.8\%, $n=32$ ). Table 1 shows the patients' distribution according to their nutritional risk and performed operation.

Table 1. Distribution of patients according to nutritional risk and type of operation.

\begin{tabular}{|c|c|c|}
\hline \multirow[t]{3}{*}{ Type of operation } & \multicolumn{2}{|c|}{ Nutritional risk } \\
\hline & $\begin{array}{c}\text { At risk } \\
(\mathrm{NRS} \geq 3)\end{array}$ & $\begin{array}{l}\text { Without } \\
\text { (NRS } \geq 3 \text { ) }\end{array}$ \\
\hline & $N(\%)$ & $N(\%)$ \\
\hline Head and neck & $4(6.7)$ & $4(12.5)$ \\
\hline Gastrointestinal & $39(65)$ & $7(21.9)$ \\
\hline Gynecological & $4(6.7)$ & $9(28.1)$ \\
\hline Urological & $10(16.7)$ & $10(31.2)$ \\
\hline Miscellany* & $3(5)$ & $2(6.2)$ \\
\hline Total & $60(65.2)$ & $32(34.8)$ \\
\hline
\end{tabular}

Patients were men (55.4\%), whereas women represented $44.6 \%$ of the sample. Men were also the majority in the group at nutritional risk (nutritional risk=38/60 (63.3\%); without nutritional risk=13/32 $(40.6 \%) ; p=0.037)$. Patients at nutritional risk presented higher mean age (64 years; SD: 10.8), when compared to those without nutritional risk (51years; SD:12.9) $(p<0.001)$ (Table 2).

Table 2. Demographic and clinical data of patients according to their nutritional risk.

\begin{tabular}{cccc}
\hline Variables & $\begin{array}{c}\text { At risk (NRS } \geq 3) \\
\text { X DP ou N (\%) }\end{array}$ & $\begin{array}{c}\text { Without risk } \\
\text { (NRS <3) } \\
\text { X DP ou N (\%) }\end{array}$ & $p^{* *}$ \\
\hline $\begin{array}{c}\text { Age } \\
\text { (years) }\end{array}$ & $64 \pm 10.8$ & $51 \pm 12.9$ & - \\
Sex & M: $38(63.3)$ & M:13 (40.6) & .037 \\
& F:22 (36.7) & F: $19(59.4)$ & \\
ASA* I II & $37(61.7)$ & $26(81.2)$ & .09 \\
$\begin{array}{c}\text { Surgical } \\
\text { duration } \\
\text { (min) }\end{array}$ & $221.62 \pm 97.496205 .91 \pm 93.806 .990$
\end{tabular}

Postoperative fasting (days)

$1.27 \pm 1.448 \quad .56 \pm 1.413$ .291

Length of

Hospital stay $\quad 9.08 \pm 10.165 \quad 4.22 \pm 3.118 \quad .049$ (days)

${ }^{\star}$ ASA: System of the American Society of Anesthesiologists to classify the patient's physiological status and surgical risks; ** $p$ values refer to the $T$-test for independent samples.

The comparisons between the two groups are shown in table 2. There was no difference regarding ASA risk, surgical duration, and postoperative fasting. However, patients at nutritional risk had a hospital stay approximately 4-5 days longer.

\section{Handgrip strength}

The HGS evolution throughout the study period is shown in figure 2 and table 3. HGS-PRE was significantly lower in the group at nutritional risk. The 
ANOVA test showed a significant reduction in HGS in both groups on the second POD $(p<0.001)$; however, it was almost back to baseline values on the 5th POD. It should be noted that the group without nutritional risk experienced a higher decrease in HGS on the second POD $(p=0.039)$.

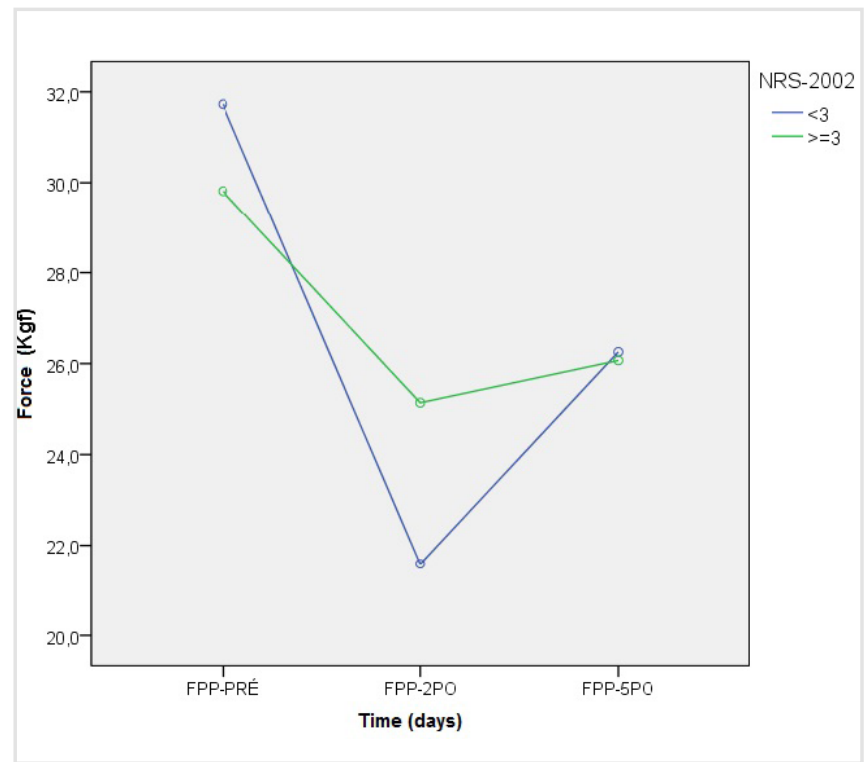

Figure 2. HGS evolution throughout the study period, for both groups.

Table 3. HGS changes in the perioperative period of patients at and without nutritional risk.

\begin{tabular}{|c|c|c|c|}
\hline \multirow{2}{*}{$\begin{array}{l}\text { Moment of } \\
\text { measurement }\end{array}$} & \multicolumn{2}{|c|}{ Nutritional risk } & \multirow{2}{*}{$\begin{array}{l}p \text { (inter- } \\
\text { group) }\end{array}$} \\
\hline & $\begin{array}{c}\text { At risk } \\
(\mathrm{NRS} \geq 3)\end{array}$ & $\begin{array}{c}\text { Without risk } \\
(\text { NRS <3) }\end{array}$ & \\
\hline HGS-PRE & $29.8 \pm 1.9$ & $31.7 \pm 3.6$ & 0.008 \\
\hline HGS-POD2 & $25.1 \pm 1.9$ & $21.6 \pm 3.6$ & 0.125 \\
\hline HGS-POD5 & $26.1 \pm 1.9$ & $26.3 \pm 3.6$ & 0.237 \\
\hline $\begin{array}{l}\text { FPP-PRE - before sur } \\
-5^{\text {th }} \text { postoperative } \\
\text { Data are described a } \\
\text { Reneated measures }\end{array}$ & $\begin{array}{l}\text { ery; FPP-POD2 - } \\
y \text {. } \\
\text { mean and stand }\end{array}$ & postoperative daj & FPP-POD5 \\
\hline
\end{tabular}

\section{DISCUSSION}

Our results, in agreement with previous studies, have shown that surgical trauma affects muscle functionality, significantly decreasing muscle strength in the postoperative period ${ }^{21,22}$. Besides, muscle functionality was affected in both groups of patients at or without previous nutritional risk. Patients without nutritional risk suffered a more significant decrease in strength, suggesting that the postoperative surgical impact on muscle functionality is greater in those patients. These data are relevant showing that adequate preoperative attention should be given regardless of the nutritional risk.

Nutritional risk, when in the presence of an underlying disease such as cancer, is an important predictive factor of postoperative complications ${ }^{3}$. Cancer is a disease that progresses with worsening of the nutritional status due to metabolic and functional risk factors. Cancer is a disease in which patients have an overall general deterioration'. In our study, we used a previously validated tool to identify the nutritional risk ${ }^{19,23}$. The NRS-2002 takes into account anthropometry, weight loss, age, type of surgery, pre-existing comorbidities, food intake etc. Thus, it was not surprising to note that the group of patients at nutritional risk was older and more frequently underwent gastrointestinal procedures. The NRS-2002 score adds one score for the elderly and two for major abdominal procedures, which explains the fact that there are more elderly and oncological digestive tract operations in the group at risk. As expected, this group also had a longer hospital stay. Our results are in agreement with several other studies ${ }^{24-30}$. Correia et al. ${ }^{25}$, Waitzberg et al. ${ }^{26}$, using several nutritional assessment tools, found that age was inversely associated with the nutritional status, especially after 60 years. A crosssectional study carried out by Bazzi et al. ${ }^{29}$ with patients undergoing elective colorectal operations showed that patients with malignant diseases had increased nutritional status deficiencies, which negatively influenced the length of hospital stay.

When preoperative HGS was assessed, patients at nutritional risk presented lower values. A previous study conducted by Flood et al. ${ }^{31}$ with cancer patients in an Australian hospital, demonstrated the relationship between an inadequate nutritional status and skeletal muscle loss. This shows that lean mass and strength loss is common among cancer patients, and negatively impacts their functionality and quality of life. The loss 
of functional capacity is especially important in surgical patients once it can affect recovery and prolong hospital stay $^{4}$. A previous study from our group has shown that low preoperative HGS is a predictor of higher postoperative mortality ${ }^{32}$.

When analyzing the changes in HGS between the preoperative period and the second postoperative day, we observed that the patients showed a decrease in muscle strength regardless of the nutritional risk. However, interestingly, patients without nutritional risk presented a more significant decrease. One explanation for these results is that patients at nutritional risk had been presenting physiological and metabolic changes for a long time before the operation ${ }^{4,13,21}$. Therefore, after the procedure, changes in muscle strength are not as striking. To our knowledge, there are no studies similar to ours and, therefore, we speculate that patients presenting compromised functional capacity and at nutritional risk when undergoing a surgical procedure do not show immediate changes in strength so markedly as when compared to individuals without nutritional risk. Our results reinforce this idea, and show that this functional impairment happened in both groups, and was statistical significant. On the fifth postoperative day, a slight recovery of the HGS was observed in both groups, which was probably associated with a positive response to medical treatment and satisfactory recovery.

In this context, prehabilitation is part of several multimodal protocols, such as ERAS ${ }^{10}$ and ACERTO ${ }^{11}$. Prehabilitation is the recommendation of a combination of physical exercises and other clinical and nutritional measures, aiming to reduce the rate of complications, especially infectious and pulmonary, and in addition, help decrease the length of hospital. Several studies and meta-analyses have shown prehabilitation programs to be effective ${ }^{33-35}$. The muscle strength loss observed in our study indirectly reinforces the recommendation for a prehabilitation program for all patients who will undergo major oncological procedures. In our understanding, improving muscle functionality should be recommended to all cancer patients undergoing major procedures, regardless of nutritional risk. However, more complications and longer hospital stay can be expected in the group at nutritional risk. However, new studies assessing whether prehabilitation benefits patients not at nutritional risk regarding postoperative complications and length of stay are necessary.

Although the current study used the standardized technique by $\mathrm{ASHT}^{20}$ to measure handgrip strength, there may besome other individual characteristics that might have impacted our results, among which are age, sex, body mass, and the height. One limitation of our study was the non-inclusion of information such as the individual's occupation, physical activity, or leisure activities, in addition to the stage and the site of the tumor as well as the preoperative nutritional therapy, which would be interesting to analyze, in future studies. Another important limitation is the heterogeneity and size of the studied sample, in addition to the information on whether or not neoadjuvant therapy had been used in the preoperative period. However, our results are of great importance as they show that the loss of muscle functionality occurs in surgical cancer patients regardless of the nutritional risk. Thus, several initiatives are needed to help optimize postoperative recovery, reducing the physical and functional repercussions associated with the surgical trauma.

\section{CONCLUSION}

Our results demonstrate that surgical procedures decrease postoperative muscle functionality in cancer patients undergoing major surgeries. Besides, this study showed that the decrease in muscle strength occurs regardless of the nutritional risk. Furthermore, patients without nutritional risk tend to have greater muscle strength impairment in the early postoperative period. Based on these results, it would be interesting to indicate preoperative prehabilitation in cancer patients regardless of their nutritional risk, to reduce the surgical impact on functional capacity.

\section{ACKNOWLEDGEMENTS}

We would like to thank the Hospital do Câncer and Hospital Santa Casa de Misericórdia, both in Cuiabá, for allowing us to develop the research in their facilities. Besides, we would like to thank the Coordenação de Aperfeiçoamento de Pessoal de Nível Superior - Brasil (CAPES) - Financing Code 001- for the financing provided. 


\title{
R E S U M O
}

\begin{abstract}
Objetivo: investigar o impacto de procedimentos cirúrgicos oncológicos na função muscular de pacientes com e sem risco nutricional. Métodos: estudo observacional realizado com pacientes oncológicos candidatos a operações de grande porte entre julho de 2018 a março de 2019 em Cuiabá, Mato Grosso, Brasil. Os pacientes foram avaliados no pré-operatório quanto ao risco nutricional pela Nutricional Risk Screening-2002 e avaliou-se a força de preensão palmar (FPP) tanto no pré- quanto no $2^{\circ}$ e $5^{\circ}$ dia de pós-operatório (PO). Resultados: Foram avaliados 92 pacientes, dos quais 55,4\% eram homens e 44,6\% mulheres, com média (DP) de idade de 64 (10,81) para pacientes com risco e $51(12,99)$ para pacientes sem risco nutricional. A avaliação nutricional pré-operatória mostrou que 34,8\% dos pacientes não tinham risco e 65,2\% apresentavam risco nutricional. A FPP foi menor $(p=0,008)$ no grupo com risco nutricional no pré-operatório. Em ambos os grupos houve queda significativa da FPP no $2^{\circ}$ dia de PO. A queda da FPP do pré-operatório para o $2^{\circ}$ dia de $P O$ foi mais pronunciada em pacientes sem risco nutricional $(p=0,039)$. Pacientes com risco nutricional apresentaram maior tempo de internação $(p=0,049)$. Conclusão: $O$ trauma cirúrgico acarreta perda da função muscular no $P O$ precoce. Pacientes sem risco nutricional apresentam queda da força muscular mais expressiva após procedimentos cirúrgicos oncológicos do que aqueles com risco nutricional. Esses resultados servem como argumento bastante forte para a implementação da Pré-habilitação em todos os pacientes candidatos a operações oncológicas de grande porte.
\end{abstract}

Palavras chave: Procedimentos Cirúrgicos Operatórios. Neoplasias. Força Muscular. Estado Nutricional. Tempo de Internação.

\section{REFERENCES}

1. Instituto Nacional de Câncer José Alencar Gomes da Silva. Consenso nacional de nutrição oncológica. Rio de Janeiro (Brasil): INCA; 2015.

2. Almeida Al, Correia $M$, Camilo $M$, Ravasco $P$. Nutritional risk screening in surgery: valid, feasible, easy! Clin Nutr. 2012;31(2):206-11.

3. Gutiérrez-Noyola A, Martos- Benítez F, Víctores $A E$, San Juan YP, Soto García A, Rodriguez LA, et al. Estado nutricional postquirúrgico del paciente oncológico al ingreso en una unidad de cuidados críticos. Rev Cubana Aliment Nutr.2015;25(1):6075.

4. Humphreys J, de la Maza P, Hirsch S, Barrera G, Gattas V, Bunout D. Muscle Strength as a Predictor of Loss of Functional Status in Hospitalized Patients. Nutrition. 2002;18(7/8):616-20.

5. Malmstrom TK, Miller DK, Simonsick EM, Ferrucci L, Morley J. SARC-F: a symptom score to predict persons with sarcopenia at risk for poor functional outcomes. J Cachexia Sarcopenia Muscle. 2016; 7(1):28-36.

6. Beaudart C, Biver E, Reginster JY, Rizzoli R, Rolland $Y$, Bautmans I, et al. Validation of the SarQoL(R), a specific health-related quality of life questionnaire for Sarcopenia. J Cachexia Sarcopenia Muscle. 2017;8(2):238-44.

7. Valkenet K, van de Port IG, Dronkers JJ, de Vries WR, Lindeman E, Backx FJ, et al. The effects of preoperative exercise therapy on postoperative outcome: a systematic review. Clin Rehabil. 2011; 25(2):99-111.

8. West MA, Wischmeyer P, Grocott MP. Prehabilitation and Nutritional Support to Improve Perioperative Outcomes. Curr Anesthesiol Rep. 2017;7(4):340-9.

9. Li C, Carli F, Lee L, Charlebois $P$, Stein B, Liberman $A S$, et al. Impact of a trimodal prehabilitation program on functional recovery after colorectal cancer surgery: a pilot study. Surg Endosc. 2013; 27(4):1072-82.

10. Nygren J, Thacker J, Carli F, Fearon KCH, Norderval $\mathrm{S}$, Lobo DN, et al. Guidelines for perioperative care in elective rectal/pelvic surgery: Enhanced Recovery After Surgery (ERAS $尺$ ) Society recommendations. Clin Nutr. 2012;31(6):801-16.

11. de-Aguilar-Nascimento JE, Salomão $A B$, Waitzberg DL, Dock-Nascimento DB, Correa MIT, Campos $A C$, et al. ACERTO guidelines of perioperative nutritional interventions in elective general surgery. Rev Col Bras Cir. 2017;44(6):633-48.

12. Schwegler I, Von Holzen A, Gutzwiller JP, Schlumpf $R$, Mühlebach S, Stanga Z. Nutritional risk is a clinical predictor of postoperative mortality and morbidity in surgery for colorectal cancer. $\mathrm{Br} \mathrm{J}$ Surg. 2010;97(1):92-7.

13. Guo W, Ou G, Li X, Huang J, Liu J, Wei H. Screening of the nutritional risk of patients with gastric carcinoma before operation by NRS 2002 and its relationship with postoperative results. J Gastroenterol Hepatol. 2010;25(4):800-3. 
14. Bozzetti F; SCRINIO Working Group. Screening the nutritional status in oncology: A preliminary report on 1,000 outpatients. Support Care Cancer. 2009;17(3):279-84.

15. Fragas RF, Oliveira MC. Risk factors associated with malnutrition in hospitalized patients. Rev Nutr. 2016;29(3):329-36.

16. Correia MI, Waitzberg DL. The impact of malnutrition on morbidity, mortality, length of hospital stay and costs evaluated through a multivariate model analysis. Clin Nutr. 2003;22(3):235-9.

17. Ma BW, Chen XY, Fan SD, Zhang FM, Huang DD, Li $B$, et al. Impact of sarcopenia on clinical outcomes after radical gastrectomy for patients without nutritional risk. Nutrition. 2019;61:61-6.

18. Sistema Único de Saúde. Programa: Fortalecimento do Sistema Único de Saúde (SUS). Relatório $N^{\circ}$ 201702541. Disponível em: https://auditoria.cgu. gov.br/download/11621.pdf

19. Kondrup J, Allison SP, Elia M, Vellas B, Plauth $M$. ESPEN guidelines for nutrition screening 2002. Clin Nutr. 2003;22(4):415-21.

20. Mathiowetz V, Kashman N, Volland G, Weber K, Dowe M, Rogers S. Grip and pinch strength: normative data for adults. Arch Phys Med Rehab.1985;66(2):69-74.

21. Desborough JP. The stress response to trauma and surgery. Br J Anaesth. 2000;85(1):109-17.

22. Schricker T, Lattermann R. Perioperative catabolism. Can J Anaesth. 2015;62(2):182-93.

23. Poziomyck AK, Fruchtenicht AV, Kabke GB, Volkweis BS, Antoniazzi JL, Moreira LF. Reliability of nutritional assessment in patients with gastrointestinal tumors. Rev Col Bras Cir. 2016;43(3):189-97.

24. Oliveira LB, Rocha Junior PB, Guimarães NM, Didnoet MT. Variáveis relacionadas ao tempo de internação e complicações no pós-operatório de pacientes submetidos à cirurgia do trato gastrointestinal. Com Ciências Saúde. 2010;21(4):319-30.

25. Correia MIT, Campos ACL; ELAN Cooperative Study. Prevalence of hospital malnutrition in Latin America: the multicenter ELAN study. Nutrition. 2003;19(10):823-5.

26. Waitzberg DL, Caiaffa WT, Correia MIT. Hospital malnutrition: the Brazilian national survey (IBRANUTRI): a study of 4000 patients. Nutrition. 2001;17(7-8):573-80.

27. Garcia RS, Tavares LRDC, Pastore CA. Rastreamento nutricional em pacientes cirúrgicos de um hospital universitário do sul do Brasil: o impacto do risco nutricional em desfechos clínicos. Einstein. 2013;11(2):147-52.

28. Coruja MK, Steemburgo T. Estado nutricional e tempo de internação de pacientes adultos hospitalizados com diferentes tipos de câncer. Braspen J. 2017;32(2):114-8.

29. Bazzi NB, Leal V, Lira Júnior HF, Santos JM, Ferreira $M G$, Zeni LAZR. Estado nutricional e tempo de jejum em pacientes submetidos a cirurgias colorretais eletivas. Nutr Clin Diet Hosp. 2016;36(2):103-10.

30. Souza VCD, Dourado KF, Lima ALC, Bernardo E, Caraciollo P. Relationship between nutritional status and immediate complications in patients undergoing colorectal surgery. J Coloproctol. 2013;33(2):83-91.

31. Flood A, Chung A, Parker $H$, Kearns V, O'Sullivan TA. The use of hand grip strength as a predictor of nutrition status in hospital patients. Clinical nutrition. 2014;33(1):106-14.

32. Bragagnolo R, Caporossi FS, Dock-Nascimento DB, de Aguilar-Nascimento JE. Handgrip strength and adductor pollicis muscle thickness as predictors of postoperative complications after major operations of the gastrointestinal tract. e-SPEN, Eur e-J Clin Nutr Metabol. 2011;6(1):e21-e26.

33. Paton F, Chambers D, Wilson P, Eastwood A, Craig $D$, Fox $D$, et al. Initiatives to reduce length of stay in acute hospital settings: a rapid synthesis of evidence relating to enhanced recovery programmes. Southampton (UK): NIHR Journals Library; 2014.

34. Beamish AJ, Chan DSY, Blake PA, Karran A, Lewis WG. Systematic review and meta-analysis of enhanced recovery programmes in gastric cancer surgery. Int J Surg. 2015;19:46-54.

35. Bruns ERJ, van den Heuvel $B$, Buskens $C J$, van Duijvendijk $P$, Festen $S$, Wassenaar EB, et al. The effects of physical prehabilitation in elderly patients undergoing colorectal surgery: a systematic review. Colorectal Dis. 2016;18(8):0267-77. 
Recebido em: 01/12/2019

Aceito para publicação em: 27/12/2019

Conflito de interesses: não.

Fonte de financiamento: nenhuma.

\section{Endereço para correspondência:}

Jessika Cadavid Sierra

E-mail: jessikacadavid.sierra@gmail.com

(c) (i) 